\title{
Hubungan Kepimpinan Guru dengan Pencapaian Akademik Pelajar di Sibu, Sarawak
}

\author{
A Relationship between Teacher Leadership with Students'Academic Achievement in \\ Primary Schools, Sibu, Sarawak
}

\author{
Khalip Musa ${ }^{\mathrm{a}}$, Nee Ngie Seng ${ }^{\mathrm{b}}$ \\ ${ }^{a, b}$ Universiti Pendidikan Sultan Idris, Malaysia, khalip@fpe.upsi.edu.my
}

\begin{abstract}
Abstrak
Tujuan utama kajian ini adalah untuk melihat hubungan kepimpinan guru dengan pencapaian akademik di sekolah-sekolah rendah daerah Sibu, Sarawak. Kepimpinan guru bagi sekolah yang berjaya melibatkan tujuh dimensi iaitu tumpuan pembangunan, pengiktirafan, autonomi, hubungan kerjasama, penyertaan, komunikasi terbuka, dan persekitaran kerja positif. Seramai 1231 orang guru telah dipilih secara rawak dari 47 buah sekolah rendah daerah Sibu. Data dikumpul dan dianalisis secara statistik deskriptif dan inferensi. Kajian ini mendapati bahawa tahap kepimpinan guru adalah tinggi $(\min =3.81$, s.p. $=0.663)$. Terdapat hubungan positif dan signifikan antara kepimpinan guru dengan pencapaian akademik pelajar $(\mathrm{r}=0.391 \mathrm{dan}$ sig $=0.000, \mathrm{p}<0.05)$. Kajian ini merumuskan bahawa kepimpinan guru di sekolah-sekolah mempunyai hubungan dengan pencapaian akademik murid. Implikasi kajian jelas menunjukkan bahawa amalan kepimpinan guru mampu mempengaruhi pencapaian akademik pelajar.
\end{abstract}

Kata kunci: kepimpinan guru, pencapaian akademik, pembangunan profesional, kepimpinan pengajaran

\begin{abstract}
The main purpose of the study was to determine the relationship between teacher leadership and students' academic achievement in primary schools in Sibu, Sarawak. The study was based on Teacher Leadership Development Model of Katzenmeyer and Moller. A total of 1231 teachers were randomly selected from 47 primary schools in Sibu. Data collected and analyzed by using descriptive and inferential statistics. The study found that the level of teacher leadership was high (mean =3.81, s.d. = 0.663). There was a positive relationship between teacher leadership and students' academic achievement in which $r=0.391$ and sig $=0.000(p<0.05)$. This finding showed that teacher leadership has a relationship with student achievement. The finding showed that teacher leadership practices is able to influence student academic achievement.
\end{abstract}

Keywords: leadership, teacher's leadership, academic achievement, professional development, instructional leadership, teaching and learning

\section{PENGENALAN}

Keputusan Ujian Pencapaian Sekolah Rendah (UPSR) 2014 merupakan keputusan terbaik dalam tempoh sebelas tahun terkini bagi negeri Sarawak (Siti Aisyah, 2014). Keputusan yang memberangsangkan ini mempunyai hubungan langsung dengan kesediaan guru melaksanakan tanggungjawab mereka dalam pengajaran dan pembelajaran. Hal ini dibuktikan dalam kajian di Sarawak oleh Abdul Said, Baharom Mohamad, Mohd Yusof Abdullah, Mohd Suhaimi Taat dan Roslee Talip (2012). Mereka menyatakan tahap kesediaan para guru merupakan faktor utama penyumbang terhadap pencapaian UPSR di Sarawak dan diikuti dengan tahap kesediaan pelajar. 
Sememangnya pencapaian akademik murid amat bergantung kepada kepimpinan guru. Menurut kajian Richardson (2011), efikasi kendiri guru yang tinggi dapat meningkatkan pencapaian akademik murid. Pencapaian akademik murid mempunyai hubungan yang signifikan terhadap dimensi pengurusan kelas, penglibatan pelajar dan strategi pengajaran guru. Guru seharusnya cekap dalam menguruskan kelas serta penggunaan strategi pengajaran bagi tujuan melibatkan murid untuk belajar. Maka, kepimpinan guru seharusnya diamalkan guru bagi meningkatkan kemahiran guru. Kejayaan sesebuah organisasi sangat bergantung kepada pemimpin. Pemimpin dikatakan mempunyai pengaruh yang besar dalam pelbagai perkara termasuk kejayaan dan kegagalan (Rahmani, Ratnawati, 2014).

Penekanan tentang kewujudan kepimpinan guru turut dinyatakan dalam kajian kepimpinan pengajaran pengetua dan kepimpinan guru yang dijalankan oleh Norashikin, Ramli, dan Nurnazahiah (2013). Menurut mereka, kepimpinan selalunya ditumpukan pada guru besar ataupun pengetua sekolah sahaja di peringkat sekolah. Namun, dalam kajian mereka turut menyatakan kewujudan satu lagi dimensi kepimpinan yang mampu meningkatkan kecemerlangan sekolah, iaitu kepimpinan guru. Dengan itu, guru mampu membuat kolaborasi dalam menyelesaikan permasalahan sekolah (Ainol Ismail, 2015).

Kepimpinan guru turut diberi penekanan sejak Kementerian Pelajaran Malaysia memperkenalkan Pelan Pembangunan Pendidikan Malaysia (PPPM) 2013-2025 (Kementerian Pendidikan Malaysia, 2013). Menurut Norashikin et al. (2013), kepimpinan di sekolah diperluas kepada guru-guru khususnya mereka yang memegang jawatan kepimpinan di sekolah. Usaha penambahbaikan sekolah bukan sahaja bergantung kepada keupayaan kepimpinan pengajaran dalam kalangan pengetua, tetapi juga melibatkan kepimpinan pengajaran guru sekolah.

Dalam kajian Taylor, Goeke, Klein, Onore, dan Geist (2011) turut menekankan kepentingan kepimpinan guru. Pembentukan dan penstrukturan program mampu membangunkan kepimpinan guru dan memberi kesan kepada pengajaran di bilik darjah serta penglibatan pembelajaran murid. Kepentingan kepimpinan guru turut disokong oleh kajian Nor Asma Sheirnawani, Mohd Asri, Rohaila, dan Hamidah (2015). Kepimpinan guru amat penting dan merupakan salah satu elemen yang harus diaplikasikan serta dipraktikkan di kalangan guru sekolah. Kepimpinan guru dapat memberi impak kepada perkembangan potensi pelajar untuk mencapai kejayaan dalam bidang kurikulum ataupun kokurikulum.

\section{PERNYATAAN MASALAH}

Pencapaian murid yang lemah sering kali dikaitkan dengan kelemahan kompetensi ataupun kecekapan pengajaran guru. Hakikat ini tidak dapat dinafikan kerana seseorang guru yang tidak cekap menyampaikan pengajaran sudah tentu tidak mampu menyampaikan pengajaran dan pembelajaran yang berkualiti kepada murid. Dalam kajian Mohd Yusri dan Aziz (2014) telah menyatakan bahawa guru yang hilang keyakinan atau efikasi akan menyebabkan kompetensi pengajaran lemah. Justeru, akan menyebabkan gejala tekanan dan burnout di kalangan guru dan menjejaskan kualiti pengajaran dan pembelajaran. Tambahan pula, kajian yang dijalankan oleh Anuar Ahmad, Siti Haishah dan Nur Atiqah (2009) turut membuktikan bahawa kompetensi pengajaran guru sejarah di lima buah sekolah daerah Perlis dan Pulau Pinang mempunyai hubungan yang signifikan terhadap pencapaian murid dalam mata pelajaran sejarah. 
Kualiti guru merupakan faktor utama menentukan keberhasilan murid. Seperti yang dinyatakan dalam PPPM anjakan empat, kualiti guru merupakan faktor yang paling signifikan dalam menentukan keberhasilan murid. Kajian Akademi Kepimpinan Pengajian Tinggi (AKEPT) pada tahun 2011 telah mendapati bahawa hanya 50\% pengajaran guru disampaikan dengan berkesan. Penyampaian pelajaran tidak melibatkan murid secukupnya dan murid pasif dalam pembelajaran serta penyampaian guru berbentuk syarahan. Tambahan pula, pengajaran guru lebih berfokus kepada pemahaman kandungan yang tidak mendalam. Malah kemahiran berfikir aras tinggi tidak dititikberatkan.

PPPM 2013-2025(Kementerian Pendidikan Malaysia, 2013) telah menyatakan bahawa terdapat perbezaan pandangan antara Jemaah Nazir dan Jaminan Kualiti (JNJK) dengan pihak sekolah terhadap pengajaran dan pembelajaran yang berkualiti di sekolah. $63 \%$ sekolah telah menilai bahawa mereka mempunyai amalan pengajaran dan pembelajaran yang baik ataupun cemerlang. Namun begitu, Pihak JNJK menyatakan bahawa hanya 13\% sekolah mengamalkan pengajaran dan pembelajaran yang berkualiti. Perbezaan sebanyak 50\% ini telah mencerminkan bahawa sekolah harus membanyakkan usaha untuk meningkatkan kemahiran pengajaran guru yang sedia ada. Justeru dapat memastikan guru-guru dapat menyampaikan pengajaran dan pembelajaran seperti yang dihasratkan.

Aziah Ismail, Loh, dan Abdul Ghani Kanesan (2015) menyatakan bahawa efikasi kendiri guru dikaitkan dengan peningkatan kualiti sesebuah sekolah melalui usaha Komuniti Pembelajaran Professional (KPP). KPP telah dilaksanakan di sekolah untuk mewujudkan dan mengekalkan kualiti guru di sesebuah sekolah. Selain itu, Nolan (2009) menjelaskan bahawa pelaksanaan KPP di sekolah dapat mengurangkan pengasingan guru, meningkatkan komitmen guru serta dapat meningkatkan strategi pengajaran dan pembelajaran guru. Namun, guru-guru masih cenderung untuk bekerja bersendirian dan jarang mengamalkan budaya perkongsian sesama guru lain dari segi pengalaman dan bahan pengajaran. Menurut Aziah et al. (2015), kekurangan perkongsian ilmu, ketiadaan perbincangan tentang kemahiran mengajar dan bertindak bersendirian akan menghalang peningkatan kemahiran pengajarannya dan sekali gus menjejaskan keberhasilan murid.

Rujukan literatur menunjukkan bahawa setakat ini belum ada kajian yang dilaksanakan baik di daerah Sibu, mahupun negeri Sarawak yang berkaitan dengan kepimpinan guru terhadap pencapaian murid UPSR terutama di sekolah rendah.

\section{TUJUAN KAJIAN}

Kajian ini bertujuan untuk melihat hubungan kepimpinan guru dengan pencapaian akademik pelajar dalam UPSR. Secara khusus, objektif kajian adalah untuk:

i. Mengenal pasti tahap kepimpinan guru.

ii. Mengenal pasti tahap pencapaian akademik UPSR.

iii. Mengenal pasti hubungan antara kepimpinan guru dengan pencapaian akademik UPSR.

\section{KERANGKA TEORETIKAL KAJIAN}

Kerangka teoretikal kajian yang digunakan dalam kajian ini adalah berdasarkan model pembangunan kepimpinan guru Katzenmeyer dan Moller(2009). Melalui penyelidikan mereka yang meliputi lebih daripada 5,000 orang guru, Katzenmeyer dan Moller telah memperolehi tujuh dimensi dalam budaya sekolah yang menyokong kepada perkembangan kepimpinan guru 
yang berjaya. Tujuh dimensi tersebut adalah: tumpuan pembangunan, pengiktirafan, autonomi, hubungan kerjasama, penyertaan, komunikasi terbuka, dan persekitaran kerja positif.

\section{KEPIMPINAN GURU}

Terdapat pelbagai definisi berkaitan kepimpinan guru. Namun, semua mempunyai tumpuan yang hampir sama iaitu mengubah peranan guru. Miller, Moon dan Elko (2000) mendefinisikan kepimpinan guru sebagai tindakan guru-guru di luar kelas yang melibatkan tanggungjawab yang jelas atau tidak untuk menyediakan pembangunan profesional kepada rakan-rakan mereka, mempengaruhi masyarakat atau daerah mereka ataupun bertindak sebagai staf tambahan untuk menyokong perubahan amalan bilik darjah dalam kalangan guru.

Frost dan Durrant (2003) menyatakan bahawa kepimpinan guru merupakan pemberian kuasa kepada guru-guru, peningkatan status profesional serta pemberian autonomi dan kawalan di sekolah. Pemberian kuasa akan memberi kesan ke atas komitmen, keberkesanan dan motivasi guru. Justeru dapat meningkatkan kemajuan sekolah, keadaan bilik darjah dan pembelajaran pelajar. Kepimpinan guru turut dilihat sebagai suatu model kepimpinan yang mengajar semua staf di setiap peringkat dalam organisasi agar berpeluang untuk memimpin melalui penumpuan terhadap amalan peningkatan pengajaran dan pembelajaran yang berlandaskan kerjasama profesional, pembangunan dan pertumbuhan dalam organisasi (Harris \& Lambert, 2003).

Katzenmeyer dan Moller (2009) mendefinisikan kepimpinan guru merupakan kemahiran guru yang memimpin di dalam dan luar kelas. Mereka mengenal pasti masalah dan menyumbang kepada komuniti guru dan para pemimpin. Selain itu, guru yang mengamalkan kepimpinan guru ini juga akan berusaha untuk mempengaruhi guru lain ke arah amalan pendidikan yang lebih baik. Mereka bersedia menjalankan tanggungjawab dan tugas mereka tanpa menunggu arahan dari guru besar. Sebaliknya mereka tahu apa yang harus dilakukan berdasarkan matlamat yang hendak dicapai.

Menurut Katzenmeyer dan Moller, setiap sekolah mempunyai gergasi yang sedang tidur iaitu kepimpinan guru. Kepimpinan guru ini mampu menjadi pemangkin kuat untuk membuat perubahan bagi tujuan meningkatkan pembelajaran pelajar. Guru merupakan kumpulan terbesar pekerja sekolah dan paling dekat dengan pelajar. Kita boleh menyedarkan gergasi yang sedang tidur ini melalui pelbagai cara. Contohnya membantu guru mengakui bahawa mereka adalah pemimpin, menawarkan peluang untuk membangunkan kemahiran kepimpinan mereka, dan mewujudkan budaya sekolah yang menghormati kepimpinan mereka. Maka kualiti guru dapat ditingkatkan agar saranan Wehling (2007) setiap kanak-kanak mempunyai seorang guru yang berkualiti tinggi dapat tercapai.

Kepimpinan beralih tumpuan daripada kepimpinan pengetua sekolah kepada kepimpinan yang diedarkan, dikongsi dan aktiviti demokrasi bersama guru. Keupayaan kepimpinan guru dapat ditingkatkan melalui usaha perkongsian ilmu profesionalisme untuk mempengaruhi semangat pelajar bagi meningkatkan pembelajaran pelajar (Durrant \& Holden, 2006). Latihan pengetua dan guru-guru harus dilaksanakan untuk memahami peranan pemimpin guru dan sokongan kepada guru. Maka guru-guru dapat bekerjasama untuk memenuhi keperluan semua pelajar di sekolah (Teacher Leadership Exploratory Consortium (TLEC), 2011).

Grant, Gardner, Kajee, Moodley \& Somaroo (2010) mengkategorikan kepimpinan guru berlaku dalam empat zon ataupun peringkat. Zon pertama, kepimpinan guru berlaku di bilik 
darjah. Zon kedua, pemimpin guru bekerja dengan guru lain di luar bilik darjah dan pembelajaran aktiviti kurikulum tambahan. Zon ketiga, kepimpinan guru di luar bilik darjah dalam aktiviti pembangunan sekolah dan zon keempat ialah kepimpinan antara sekolahsekolah dalam komuniti.

TLEC (2011) menyatakan bahawa guru-guru yang mengambil peranan kepimpinan harus bekerjasama dengan pengetua dan pentadbir sekolah lain bagi memudahkan penambahbaikan dalam pengajaran serta menggalakkan amalan pengajaran yang terbaik di kalangan rakan-rakan mereka demi pembelajaran pelajar. Dengan berbuat demikian, mereka mendapat sokongan daripada pemimpin sekolah dalam menggalakkan inovasi dan mewujudkan budaya kejayaan di sekolah. Selain itu, mereka akan mempengaruhi rakan setugas mereka dalam konteks yang rasmi dan tidak rasmi (Grant, 2006) serta menyokong struktur pasukan kolaboratif di sekolahsekolah mereka.

\section{Evolusi Kepimpinan Guru}

Kepimpinan guru telah melalui proses evolusi selama 35 tahun. Evolusi ini telah dibahagi kepada tiga peringkat yang dinyatakan oleh Silva, Gimbert, dan Nolan (2000). Gelombang pertama kepimpinan guru bermula pada awal 1980-an. Dalam tempoh ini, peranan kepimpinan formal seperti guru besar, guru pakar, ketua jabatan, dan wakil kesatuan telah diwujudkan untuk guru (Little, 2003). Namun, kedudukan kepimpinan bertumpu pada peranan pengurusan dan pentadbiran di sekolah. Kepimpinan pengajaran telah diabaikan.

Gelombang kedua bermula pada pertengahan hingga lewat 1980-an (Silva et al., 2000). Kepentingan kepakaran pengajaran guru telah diakui dan jawatan-jawatan seperti pemimpin pasukan, pemaju kurikulum, mentor guru, dan penyertaan dalam pembangunan profesional bersama rakan-rakan guru telah diwujudkan. Selain kewujudan jawatan-jawatan itu, sistem pampasan yang berbentuk kenaikan gaji turut dilaksanakan. Jawatan kepimpinan untuk guruguru merupakan komponen penting dalam sistem pendidikan. Namun begitu, jawatan kepimpinan yang diperolehi oleh guru tidak mempunyai kuasa untuk membuat perubahan terhadap sekolah (Wiggenton, 1992).

Gelombang ketiga bermula dari lewat tahun 1980-an. Kepimpinan guru menekankan budaya yang menyokong keserakanan, kerjasama, dan pembelajaran berterusan di kalangan guru (Silva et al., 2000). Guru-guru berkongsi amalan terbaik bersama rakan mereka, melibatkan diri dalam pentadbiran sekolah bersama dengan pengetua, menyertai dalam membuat keputusan untuk sekolah, dan meluaskan pengetahuan mereka melalui aktiviti penyelidikan atau kerjasama (Lieberman \& Miller, 2005).

Menurut Katzenmeyer dan Moller (2009), konsep kepimpinan guru telah diperkenalkan pada pertengahan tahun 1990an. Ketika itu, konsep kepimpinan guru masih kurang jelas di kalangan guru besar. Guru besar yang belajar bersama dengan guru-guru mengenai reformasi sekolah lebih cenderung untuk memindahkan pembelajaran mereka dari bengkel pembangunan profesional kepada kerja-kerja di sekolah. Malangnya, banyak guru besar telah dipindahkan ke sekolah lain. Inisiatif di sekolah tersebut turut terjejas akibat guru besar baharu. Guru-guru yang telah belajar bersama dengan bekas guru besar berasa kecewa dan tidak berkuasa untuk mengekalkan usaha penambahbaikan sekolah.

Menurut Katzenmeyer dan Moller (2009), kini kepimpinan guru merupakan satu istilah yang lebih biasa seperti yang dibuktikan oleh pertumbuhan pesat bilangan jawatan kepimpinan 
pengajaran, kemasukan kepimpinan guru sebagai pengukuran standard guru, dan percambahan kesusasteraan kepimpinan guru. Sebab utama kemunculan kepimpinan guru adalah disebabkan sistem sekolah telah menyedari bahawa pembangunan profesional yang ditawarkan kepada guru-guru tidak akan menyebabkan perubahan tingkah laku di dalam bilik darjah kecuali dengan bimbingan susulan dan sokongan yang ditawarkan. Pemimpin guru telah pun diberi gelaran seperti jurulatih literasi, mentor, dan guru pakar yang akan membimbing guru di sekolah. Guru yang mengamalkan kepimpinan guru akan keluar dari bilik darjah. Tambahan pula, bilangan jurnal, laporan penyelidikan, dan buku-buku berkaitan kepimpinan guru yang semakin meningkat turut menjadi pemangkin kepada kewujudan kepimpinan guru (Mangin \& Stoelinga, 2008).

\section{METODOLOGI KAJIAN}

Kajian ini merupakan kajian kuantitatif bentuk deskriptif dan inferensi. Statistik deskriptif digunakan bagi mengukur tahap kepimpinan guru dan tahap pencapaian akademik murid. Statistik inferensi korelasi digunakan untuk mengukur hubungan kepimpinan guru terhadap pencapaian akademik UPSR murid.

Populasi kajian merupakan sekumpulan orang yang dijadikan tumpuan penyelidikan dan kesimpulan kajian akan merujuk kepada populasi ini (Hamidah, Jamal \& Khalip, 2014). Dalam kajian ini, populasi merujuk kepada guru-guru yang mengajar di sekolah rendah daerah Sibu. Terdapat sejumlah 1,231 orang guru dari 47 buah sekolah rendah terlibat sebagai polulasi kajian. Pensampelan merupakan proses memilih sebilangan responden kajian daripada sesuatu populasi (Chua, 2011). Saiz sampel kajian ini ditentukan berdasarkan jadual penentuan saiz sampel Krejcie dan Morgan (1970). Berdasarkan jadual saiz sampel, sebanyak 291 orang guru dipilih sebagai sampel daripada 1231 orang.Instrumen 49 item kepimpinan guru Teacher Leadership School Survey(TLSS) daripada Katzenmeyer dan Moller (2009) telah diterjemah dan disesuaikan dengan sosio budaya tempatan menjadi instrumen utama kajian.

\section{DAPATAN KAJIAN}

Soalan kajian pertama ialah untuk mengenal pasti tahap kepimpinan guru. Dapatan kajian telah dianalisis dengan menentukan tahap min bagi menentukan tahap kepimpinan guru. Jadual $1 \mathrm{di}$ bawah menunjukkan skor min kepimpinan guru ialah sebanyak 3.81. Ini menunjukkan bahawa tahap kepimpinan guru adalah berada pada tahap tinggi.

Jadual 1: Keputusan analisis skor min tahap kepimpinan guru

\begin{tabular}{cccc}
\hline Pemboleh Ubah & Min & Sisihan Piawai & Tahap \\
\hline Kepimpinan Guru & 3.81 & 0.663 & Tinggi \\
\hline
\end{tabular}

Soalan kajian kedua ialah untuk mengenal pasti tahap pencapaian akademik UPSR. Dapatan kajian juga telah dianalisis dengan menentukan tahap min bagi menentukan tahap pencapaian akademik UPSR. Gred Purata Sekolah (GPS) bagi tahun 2013, 2014, dan 2015 telah dikira untuk mendapatkan GPS Purata. Selepas itu, GPS Purata akan diterbalikkan. Berdasarkan 
Jadual 2 di bawah, skor min 2.59 menunjukkan bahawa tahap pencapaian akademik UPSR adalah pada tahap sederhana.

Jadual 2: Keputusan analisis skor min tahap pencapaian akademik

\begin{tabular}{cccc}
\hline Pemboleh Ubah & Min & Sisihan Piawai & Tahap \\
\hline Pencapaian akademik & 2.59 & 0.361 & Sederhana \\
\hline
\end{tabular}

Soalan kajian ketiga ialah untuk mengenal pasti hubungan antara kepimpinan guru dengan pencapaian akademik UPSR. Ujian korelasi telah digunakan dalam analisis untuk mendapatkan jawapan bagi soalan kajian ini. Berdasarkan Jadual 3, hubungan antara kepimpinan guru terhadap pencapaian akademik UPSR adalah signifikan ( $\mathrm{p}=.000, \mathrm{p}<0.05)$.

\section{Jadual 3: Keputusan korelasi antara kepimpinan guru terhadap pencapaian akademik}

\begin{tabular}{llcc}
\hline \multicolumn{3}{c}{ Kolerasi } & \\
\hline & & Kepimpinan guru & Pencapaianakademik UPSR \\
& Pearson Correlation & 1 & $.391^{* *}$ \\
Kepimpinan guru & Sig. (2-tailed) & & .000 \\
& $\mathrm{~N}$ & 276 & 276 \\
Pencapaianakademi & Pearson Correlation & $.391^{* *}$ & 1 \\
k UPSR & Sig. (2-tailed) & .000 & 276 \\
& $\mathrm{~N}$ & 276 & \\
\hline ***ap signifikan & &
\end{tabular}

**Tahap signifikan adalah pada aras $\mathrm{p}<0.05$ (ujian 2 ekor)

\section{RUMUSAN KAJIAN}

Secara keseluruhan, didapati tahap kepimpinan guru adalah tinggi. Kepimpinan guru diuji melalui domain budaya sekolah yang menyokong kepada pembentukan kepimpinan guru yang disarankan oleh Katzenmeyer dan Moller (2009) iaitu tumpuan pembangunan, pengiktirafan, autonomi, hubungan kerjasama, penyertaan, komunikasi terbuka dan persekitaran yang positif. Dapatan kajian ini adalah selari dengan kajian Norashikin et al. (2015), bahawa tahap kepimpinan guru di 40 buah sekolah menengah harian di negeri Johor, Malaysia adalah pada tahap yang tinggi. Keenam-enam dimensi yang dikaji iaitu penilaian kendiri dan membuat perubahan, kepelbagaian, kemahiran pengajaran, organisasi kendiri, penambahbaikan yang berterusan dan komunikasi adalah pada tahap yang tinggi. Dalam kajian Siti Aida (2011) turut menunjukkan bahawa amalan kepimpinan guru adalah pada tahap tinggi dalam kalangan guruguru sains dan matematik sekolah menengah di Shah Alam. Guru yang mengamalkan kepimpinan guru akan sentiasa memikirkan cara untuk memajukan sekolah walaupun sekolahnya sudah berjaya.

Tahap pencapaian akademik UPSR adalah pada tahap sederhana iaitu pada min 2.59. Gred Purata Negeri UPSR tahun 2015 adalah 2.48 berbanding 2.52 pada tahun 2014. Dengan ini dapat disimpulkan bahawa tahap pencapaian murid daerah Sibu adalah lebih tinggi iaitu GPS 2.59 berbanding dengan Gred Purata Negeri UPSR Sarawak. 
Kajian ini turut mendapati terdapat hubungan yang signifikan antara kepimpinan guru dengan pencapaian akademik pelajar namun pada aras lemah lemah $(\mathrm{r}=0.391)$. Dapatan ini adalah selari dengan dapatan kajian Norashikin et al. (2015) yang mempunyai hubungan yang signifikan antara kepimpinan guru dengan pencapaian akademik pelajar pada tahap rendah. Dapatan mereka menunjukkan bahawa kepimpinan guru bagi dimensi penilaian kendiri dan membawa perubahan, kemahiran pengajaran, komunikasi, organisasi kendiri, dan penambahbaikan yang berterusan mempunyai kaitan yang lemah terhadap pencapaian akademik murid.

Dalam kajian Berry, Daughtrey dan Wieder (2010) wujudnya hubungan yang rapat antara kepimpinan guru dengan pencapaian akademik pelajar. Kajian mereka telah mendedahkan bahawa guru-guru yang berpengalaman akan bekerja bersama-sama di sekolah dapat menghasilkan lebih ramai pelajar yang cemerlang dalam keputusan. Selain itu, hasil kajian mereka turut membuktikan bahawa bantuan dan sokongan dari rakan sekerja kepada guru baharu dapat meningkatkan pencapaian akademik pelajar.

Dalam kajian Siti Aida (2011), yang menunjukkan bahawa amalan kepimpinan guru mempunyai hubungan dengan keupayaan kepimpinan guru yang merangkumi aspek kemahiran pengajaran, pengurusan bilik darjah dan perancangan pengajaran mampu meningkatkan keberkesanan kepimpinan guru terutamanya di dalam bilik darjah. Menurut Abdul Ghani (2009), kepimpinan guru adalah satu proses seseorang guru mempengaruhi pelajarnya ke arah mencapai matlamat yang ditetapkan secara bersama. Kepimpinan guru dapat meningkatkan pencapaian pelajar sekiranya guru dapat berjaya mendidik dan membentuk tingkah laku positif pelajarnya.

\section{PERBINCANGAN}

Menurut Katzenmeyer dan Moller (2009), setiap sekolah mempunyai gergasi yang sedang tidur iaitu kepimpinan guru. Kepimpinan guru ini mampu menjadi pemangkin kuat untuk membuat perubahan bagi tujuan meningkatkan pembelajaran pelajar. Guru merupakan kumpulan terbesar pekerja sekolah dan paling dekat dengan pelajar. Kita boleh menyedarkan gergasi yang sedang tidur ini melalui pelbagai cara. Kita boleh membantu guru mengakui bahawa mereka adalah pemimpin, menawarkan peluang untuk membangunkan kemahiran kepimpinan mereka, dan mewujudkan budaya sekolah yang menghormati kepimpinan mereka.

Namun begitu, setiap sekolah mempunyai tahap kepimpinan gurunya yang berlainan. Menurut Katzenmeyer dan Moller (2009), guru perlu meneroka dapatan soal selidik dalam TLSS dan membuat definisi sendiri berkaitan kepimpinan guru sekolahnya dan memikirkan keperluan kepimpinan guru dalam membuat penambahbaikan dan perubahan di sekolah. Melalui kajian yang dijalankan berdasarkan soal selidik TLSS ini, pihak sekolah dapat menentukan penambahbaikan yang diperlukan.

Komuniti Pembelajaran Profesional (KPP) merujuk kepada amalan kolaboratif dalam kalangan pendidik yang berkomitmen dan secara bersama-sama menetapkan matlamat atau membina wawasan dan berusaha secara kolektif mencapai matlamat yang ditetapkan. KPP telah dilaksanakan dan digalakkan menjadi suatu budaya di sekolah. Amalan KPP dapat meningkatkan pembelajaran wujud dalam organisasi. Pembangunan profesionalisme dapat ditingkatkan secara berterusan sepanjang kerjaya(DuFour et al., 2006). Selain itu, KPP juga merupakan satu strategi yang dapat meningkatkan pencapaian murid melalui pewujudan 
budaya sekolah secara kolaboratif yang berfokuskan pada pembelajaran (Feger \& Arruda, 2008).

Selain itu, kepimpinan guru menekankan budaya yang menyokong keserakanan, kerjasama, dan pembelajaran berterusan di kalangan guru (Silva et al., 2000). Pembelajaran berterusan yang dinyatakan ini merujuk kepadaPembangunan Profesionalisme Berterusan (PPB). Guruguru haruslah melibatkan diri dalam PPB untuk meningkatkan kualiti pengajaran masingmasing. Budaya bimbingan rakan sejawatan diwujudkan dalam sistem pendidikan yang baharu ini melalui pementoran, peningkatan kebertanggungjawaban rakan sejawat serta pembangunan dan perkongsian amalan terbaik di kalangan guru. Menurut Saedah dan Mohammed Sani (2012), sekolah harus menjalankan sistem pementoran untuk memastikan semua guru baharu mendapat bimbingan dan justeru meningkatkan kualiti profesional guru. Tanggungjawab ini telah dipikul oleh ketua panitia dan guru cemerlang di sekolah.

Aktiviti PPB ini menggalakkan guru membimbing sesama sendiri, membangunkan dan menyebarluaskan amalan terbaik terhadap pencapaian standard profesional guru (KPM, 2014). Guru didedahkan dengan budaya kerjasama dan kecemerlangan profesional. Maka, guru bekerjasama dalam menangani masalah melalui perkongsian amalan terbaik. Mereka mempunyai keluwesan pedagogi di dalam bilik darjah untuk memastikan setiap murid belajar. Lantaran itu, mulai 2025, diharapkan kementerian dapat membudayakan kecemerlangan berlandaskan teladan dari rakan setugas dan proses pensijilan(KPM, 2013).

Namun begitu, pencapaian murid bukan semata-matanya bergantung kepada kepimpinan guru sahaja. Dalam kajian Abdul Said et al., (2012) menyatakan tahap kesediaan guru paling tinggi manakala tahap kesediaan murid adalah paling rendah. Dengan ini dapat disimpulkan bahawa, kesediaan murid turut merupakan pengaruh terhadap pencapaian akademik pelajar. Seperti yang dinyatakan dalam kajian Mohd Mohd Najib dan Nor Shafrin (2008), murid-murid harus menguasai kemahiran belajar kerana ia adalah signifikan dengan pencapaian akademik pelajar.

Amalan KPP memerlukan kepimpinan guru. Pendedahan tentang kepimpinan guru turut dapat meningkatkan pencapaian murid. Nor Asma et al. (2015) dalam kajian mereka menekankan kepentingan amalan kepimpinan guru terhadap pencapaian pelajar. Ramai pelajar mencapai pencapaian akademik yang cemerlang dengan adanya kepimpinan sekolah yang melibatkan guru-guru dalam membuat keputusan. Seperti yang dijelaskan dalam PPPM 2013-2025, peningkatan komitmen guru sebagai pemimpin dan pengurus pembelajaran di bilik darjah mampu menambahbaikkan kualiti pengajaran dan pembelajaran di sesebuah sekolah. Menurut Jackson, Burrus, Bassett, dan Roberts (2010), kepimpinan guru ialah proses yang dilakukan oleh guru secara individu ataupun kolektif bagi tujuan mempengaruhi diri, rakan guru, guru besar dan ahli lain dalam komuniti sekolah untuk memperbaiki amalan pengajaran dan pembelajaran bagi tujuan meningkatkan pembelajaran dan pencapaian murid.

\section{RUMUSAN}

Kepimpinan guru memainkan peranan yang semakin penting dalam meningkatkan pencapaian akademik pelajar. Sebagai orang yang paling banyak berada dalam bilik darjah dan terlibat secara langsung dalam proses utama persekolahan iaitu pengajaran dan pembelajaran, keupayaan guru untuk menjadi pemimpin dengan mengamalkan ciri-ciri kepimpinan guru semakin kritikal. Pengajaran yang berkesan akan memberi impak yang besar kepada kemajuan dan pencapaian pelajar. Perkongsian amalan pengajaran yang berkesan dengan rakan sekerja 
dan komuniti luar akan berupaya meningkatkan pencapaian pelajar pada skala yang lebih besar. Kepentingan kepimpinan guru ini harus diberi perhatian serius kerana para sarjana telah mengesahkan tentang kepentingan kepimpinan guru dalam meningkatkan pencapaian akademik murid di sekolah (Berry et al., 2010; Katzenmeyer \& Moller, 2009). Kajian ini diharap dapat memberikan kefahaman dan pengetahuan dan seterusnya meningkatkan amalan kepimpinan guru bagi meningkatkan pencapaian akademik pelajar.

\section{RUJUKAN}

Abdul Ghani Abdullah. (2009. Kepimpinan dan penambahbaikan sekolah. Kuala Lumpur: PTS Profesional.

Abdul Said, Baharom Mohamad, Mohd Yusof Abdullah, Mohd Suhaimi Taat, Roslee Talip. (2012. Kajian terhadap faktor penyumbang terhadap pencapaian sifar UPSR di Sarawak - Satu kajian tinjauan. Seminar kebangsaan majlis dekan pendidikan IPTA 2012.

Ainol Ismail. (2015). Elak sifat 'heroisme' di sekolah. Utusan online. Dimuat turun dari http: //www.utusan.com.my.

Anuar Ahmad, Siti Haishah Abdul Rahman, Nur Atiqah T. Abdullah. (2009). Tahap keupayaan pengajaran guru sejarah dan hubungannya dengan pencapaian murid di sekolah berprestasi rendah. Jurnal pendidikan Malaysia, 34(1).

Aziah Ismail, Loh Hooi Yen, Abdul Ghani Kanesan Abdullah. (2015). Komuniti pembelajaran profesional dan efikasi kendiri guru sekolah menengah di Pulau Pinang. Jurnal Kepimpinan Pendidikan, 2(1).

Berry B, Daughtrey A,Wieder, A. (2010). Teacher Leadership: Leading the Way to Effective Teaching and Learning. Center for Teaching Quality. Dimuat turun dari http://www.teachingquality.org/content/teacher-leadership-leading-way-effective-teaching-andlearning pada 22 Januari 2016.

Chua Yan Piaw. (2011). Kaedah penyelidikan. Kuala Lumpur, Malaysia: McGraw Hill Companies.

DuFour R, Eaker R, Many, T. (2006). Learning by doing: A handbook for professional learning communities at work. Bloomington, IN: Solution Tree.

Durrant J, Holden G. (2006). Teachers leading change. (Alma Harris, Ed.). London, UK: Paul Chapman. Feger S, Arruda E. (2008). Professional learning communities: key themes from the literature. Providence, RI: The Education Alliance, Brown University.

Frost D, Durrant J. (2003). Teacher-led development work: guidance and support. David Fulton, London.

Grant C. (2006). Emerging voices on teacher leadership: Some South African view. Educational management administration and leadership, 34(4), 511-532.

Grant C, Gardner K, Kajee F, Moodley R, Somaroo S. (2010). Teacher leadership: a survey analysis of KwaZulu-Natal teachers' perceptions. South African Journal of Education, 30:401-419.

Hamidah Yusof, Jamal Yunus, \& Khalip Musa. (2014). Kaedah penyelidikan pengurusan pendidikan. Perak: Universiti Pendidikan Sultan Idris.

Harris A, Lambert L. (2003). Building leadership capacity for school improvement. Open University Press, London.

Jackson T, Burrus J, Bassett K, Roberts R. (2010). Teacher leadership: an assessment framework for an emerging area of professional practice. ETS research report series, 10(2), 11-41.

Katzenmeyer M, Moller G. (2009). Awakening the sleeping giant: helping teachers develop as leaders (3rd Ed). Thousand Oaks: Corwin Press.

Kementerian Pendidikan Malaysia. (2013). Pelan pembangunan pendidikan Malaysia 2013-2025. Kementerian Pendidikan Malaysia, Putrajaya, Malaysia.

Kementerian Pendidikan Malaysia. (2014). Pelan pembangunan profesionalisme berterusan (Guru dan pemimpin sekolah). Kementerian Pendidikan Malaysia, Putrajaya, Malaysia.

Krejcie RV, Morgan DW. (1970). Determining sample size for research activities. Educational and Psychological Measurement, 30, 608.

Lieberman A, Miller L. (2005). Teachers as leaders. The Educational Forum, 69, 151-159. 
Little JW (2003) Constructions of teacher leadership in three periods of policy and reform activism. School Leadership and Management, 23(4), 401-419.

Miller B, Moon J, Elko S. (2000). Teacher leadership in math and: casebook and facilitator's guide. Heinemann, Portsmouth, NH.

Mohd Najib Abdul Aziz, Nor Shafrin Ahmad. (2008). Kemahiran belajar dan hubungannya dengan pencapaian akademik: kajian di daerah Kerian, Perak. Jurnal Pendidik dan Pendidikan, 23, 29 47.

Mohd Yusri Ibrahim, Aziz Amin. (2014). Model kepimpinan pengajaran pengetua dan kompetensi pengajaran guru. Jurnal Kurikulum dan Pengajaran Asia Pasifik, 2(1).

Nolan, D. (2009). A study of the relationship of teachers' self-efficacy and the impact of professional learning community as an organizational structure. Louisiana: Louisiana Tech University.

Nor Asma Sheirnawani Abdul Rahman, Mohd Asri Mohd Noor, Rohaila Yusof, Hamidah Yusof. (2015). Kesahan model amalan kepimpinan guru. JuKu: Jurnal kurikulum dan pengajaran Asia Pasifik, 3(2).

Norashikin Abu Bakar, Ramli Basri, Foo Say Fooi. (2015). Hubungan kepimpinan guru dengan pencapaian akademik Pelajar. International Journal of Education and Training, 1(2).

Norashikin Abu Bakar, Ramli Basri, Nurnazahiah Abas. (2013). Kepimpinan pengajaran pengetua dan kepimpinan guru. Seminar pasca siswazah dalam pendidikan, 419 - 430.

Rahmani Timorita Yulianti, Ratnawati Yuni Suryandari. (2014). Suatu ulasan kritis tentang kepimpinan dalam membangun profesionalisme institusi zakat. GEOGRAFIA Online, Malaysian Journal of Society and Space, 10(2), 143-153.

Richardson, GE. (2011). Teacher efficacy and its effects on the academic achievement of African Amarican students. Unpublished dessertation, Greeleaf University.

Saedah Siraj, Mohammed Sani Ibrahim. (2012). Standard kompetensi guru Malaysia. Dimuat turun dari http://www.medc.com.my/medc/seminar_medc/fromCD/pdf/159.pdf pada 11 Disember 2015.

Silva DY, Gimbert B, Nolan J. (2000). Sliding the doors: locking and unlocking possibilities for teacher leadership. Teachers college record, 102(4), 779-804.

Siti Aida. (2011). Kepimpinan guru dalam meningkatkan kualiti pengajaran dan pembelajaran di sebuah sekolah mengah harian di Shah Alam. Tesis Sarjana Kepengetuaan. Institut Kepimpinan Pendidikan: Universiti Malaya, Malaysia.

Siti Aisyah Ramli. (2014). Terus cemerlang. GPN 2.52 untuk UPSR 2014 menyamai tahun lepas, prestasi terbaik Sarawak dalam 11 tahun. Berneo Post Online. Dimuat turun dari http://www.theborneopost.com.

Taylor M, Goeke J, Klein, E, Onore C, Geist K. (2011). Changing leadesrship: teachers lead the way for schools that learn. Teaching and teacher education, 27,920 - 929.

Teacher Leadership Exploratory Consortium. (2011). Teacher leader model standards. Dimuat turun dari http://www.nea.org/assets/docs/TeacherLeader ModelStandards2011.pdf pada 7 Disember 2015.

Wehling B. (2007). Building a 21st century U.S. education system. Washington, DC: The National Commission on Teaching and America's Future (NCTAF).

Wiggenton E. (1992). A vision of teacher leadership. In the teachers' voice. In C. Livingston (Ed.), Teachers as leaders: Evolving roles (167-173). Washington, DC: NEA.

Youitt D. (2007). Teacher leadership: snother way to add value to schools. Perspectives on educational leadership. Australian Council for Educational Leaders, November, Winmalee, NSW. 